\title{
Deformed Microstructures and Mechanical Properties of CP-Ti Processed by Multi-Pass ECAP at Room Temperature
}

\author{
Yang Xirong, Zhao Xicheng, Fu Wenjie \\ Xi'an University of Architecture \& Technology, Xi'an 710055, China
}

\begin{abstract}
The deformed microstructures and mechanical properties of commercial pure titanium (CP-Ti) with an initial grain size of about $28 \mu \mathrm{m}$ was investigated using equal channel angular pressing (ECAP). ECAP was conducted at room temperature adopting a die with a channel angle of $120^{\circ}$ via route $\mathrm{B}_{\mathrm{C}}$. Special attention was paid on the microstructure evolution and mechanical properties of the ECAP samples. Deformation twins were found in most grains after the first and second pass of ECAP. After four ECAP passes, the original grains were refined from $28 \mu \mathrm{m}$ to about $250 \mathrm{~nm}$, and the ultimate strength and microhardness were significantly enhanced to $773 \mathrm{MPa}$ and $2486 \mathrm{MPa}$, respectively. Meanwhile good ductility of $16.8 \%$ elongation still remained.
\end{abstract}

Key words: ECAP; CP-Ti; microstructure; mechanical properties

Equal channel angular pressing (ECAP), as a severe plastic deformation (SPD) technique, has recently attracted more and more attentions because of its usefulness in producing bulk materials with ultra-fine-grains (UFG) ${ }^{[1,2]}$. Up to now, there are many reports on UFG materials processed by ECAP, such as Al alloys, $\mathrm{Cu}, \mathrm{Ni}$, low-carbon-steel and $\mathrm{Mg}$ alloy, which belong to the materials with face centered cubic (fcc) and body centered cubic (bcc) ${ }^{[3-8]}$. For CP-Ti, hexagonal close packed (hcp) metal, it is difficult to achieve ECAP deformation at room temperature due to the limited slip systems compared with cubic metals ${ }^{[9]}$. For the purpose of enhancing the deformability of hard-to-deform metals, CP-Ti was usually processed by ECAP at high temperatures in previous works ${ }^{[10-15]}$. However, higher processing temperature might increase the rate of dynamic recrystallization resulting in lower strength.

In this work, ECAP deformation for CP-Ti was carried out at room temperature by enlarging the intersecting angle of $\phi$. The development of the deformed microstructures and mechanical properties of the as-pressed samples were focused on.

\section{Experimental}

A hot rolled plate of commercial purity titanium, grade 2 (CP-Ti), with an average grain size of $28 \mu \mathrm{m}$ was used as the starting material in the present investigation. Its composition (mass fraction) was $0.13 \mathrm{O}, 0.004 \mathrm{H}, 0.01 \mathrm{~N}, 0.04 \mathrm{C}$, and 0.12 $\mathrm{Fe}$. The plate was cut along rolling direction into several pieces, which were machined to samples with $15 \mathrm{~mm} \times 15$ $\mathrm{mm} \times 80 \mathrm{~mm}$ used as experimental billets. A die-set with an internal angle $\phi$ of $120^{\circ}$ and an outer curvature angle $\psi$ of $20^{\circ}$ was adopted, which gave an equivalent plastic strain of about 0.635 on each pressing according to the following equation ${ }^{[16]}$.

$$
\varepsilon=\frac{1}{\sqrt{3}}\left[2 \cot \left(\frac{\phi}{2}+\frac{\psi}{2}\right)+\psi \operatorname{cosec}\left(\frac{\phi}{2}+\frac{\psi}{2}\right)\right]
$$

All billets were processed at room temperature 4 passes with $B_{C}$ route, in which the sample was rotated by $90^{\circ}$ in the same sense in each pass. A composite lubricant was used, here in graphite was the main component. After each ECAP pressing, Ti billets were annealed immediately at $200{ }^{\circ} \mathrm{C}$ for $1 \mathrm{~h}$ to remove residual stress.

To observe microstructures, optical microscopy (OM) and transmission electron microscopy (TEM) samples were cut from their transverse sections. Thespecimens for TEM anal ysis were prepared first by mechanical polishing, then by twin jet polishing with a solution of $5 \%$ perchloric acid, $35 \%$ butanol and $60 \%$ methanol at an applied potential of $40 \mathrm{~V}$ and at

\footnotetext{
Received date: November 25, 2008

Foundation item: Supported by the National Nature Science Foundation of China (50874086); Special Programs Foundation of Ministry of Education of Shaanxi Province (07JK307); the Nature Science Foundation of Shaanxi Province (2005 $\mathrm{E}_{1} 05$ )

Biography: Yang Xirong, Candidate for Ph.D., Associate Professor, School of Metallurgical Engineering, Xi'an University of Architecture \& Technology, Xi'an 710055, P. R. China, Tel: 0086-29-82205561

Copyright (C) 2009, Northwest Institute for Nonferrous Metal Research. Published by Elsevier BV. All rights reserved.
} 
$233 \mathrm{~K}$.

Mechanical tensile tests were carried out at room temperature using a universal testing machine with a displacement rate of $1 \mathrm{~mm} / \mathrm{min}$. Test samples with a gauge section of $4 \mathrm{~mm}$ (width) $\times 10 \mathrm{~mm}$ (length) $\times 2 \mathrm{~mm}$ (thickness) and $5 \mathrm{~mm}$ shoulder radius were taken from the CP-Ti billets along its longitudinal axis. Yield strength (YS), ultimate tension strength (UTS) and elongation to failure were measured. The microhardness was measured, and the average of ten measurents was taken as the microhardness of the sample.

\section{Results and Discussion}

\subsection{Microstructures}

Fig.1a shows a typical optical microstructure of the as-received $\mathrm{CP}-\mathrm{Ti}$, which shows the microstructure consisting of nearly equiaxed grains with an average size of $28 \mu \mathrm{m}$. During the first ECAP pass at room temperature, the grains were subjected to pure shear deformation, and were elongated along the direction of about $30^{\circ}$ inclined to the longitudinal direction (Fig.1b). Compared with Fig.1a, it can be seen that the deformation microstructure after first ECAP pass is significantly fined than the initial microstructure. In addition, a large number of twins in grains can be found. The twin direction is nearly parallel to the elongation direction. Some twins even pass through the entire grain and form macro-twins ${ }^{[14-15]}$

Fig. 2 shows TEM images of the microstructure of $\mathrm{CP}$ Ti after one ECAP pass. As shown in Fig.2a, the microstructure presents elongated band structure. The average width of the bands is approximately $0.4 \mu \mathrm{m}$. Within these bands, high dislocation densities appear. Large number of dislocation tangle, pile up and change into dislocation cell blocks. In order to characterize the bands, a selected area electron diffraction (SAED) pattern from a region containing two adjacent bands (Marked "A" in Fig.2a) present blurred spots, shown in Fig.2b, indicating that the bands are low angle boundary formed by slip and high internal stresses existing in the structure. The bands with low angle boundary, i.e. shear band structure, have been reported to be the typical microstructure of ECAP pressed cubic structural metal ${ }^{[5-8]}$.

Deformed twins are shown in Fig.2c, and these twin bands are finer than shear bands mentioned above, only $0.2 \mu \mathrm{m}$. A SAED pattern from the region containing two adjacent bands was taken using a $[10 \overline{1} 2]$ zone axis (Fig.2d). The pattern

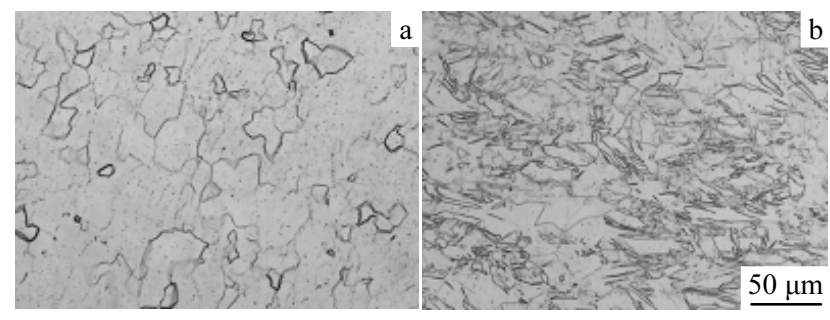

Fig.1 Optical microstructure: (a) as-received CP-Ti; (b) CP-Ti after first ECAP pass at room temperature

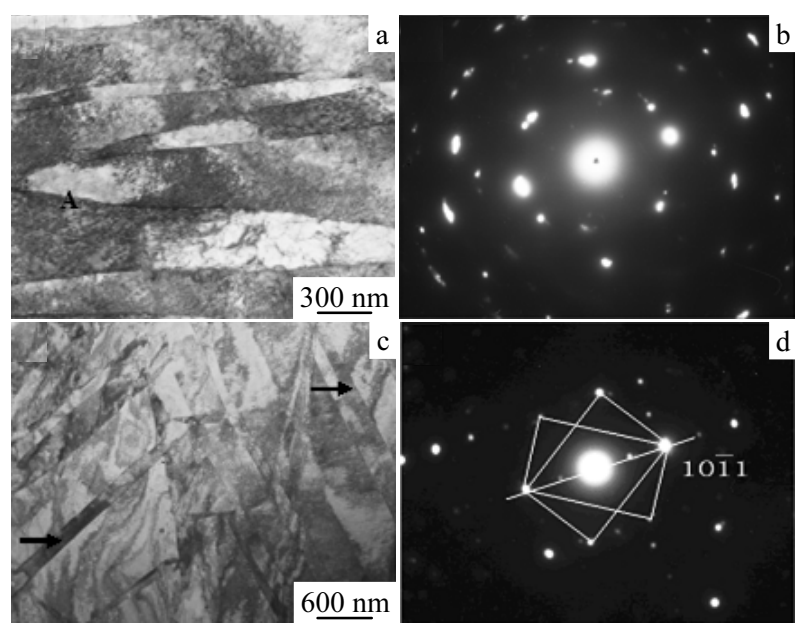

Fig.2 TEM images of CP Ti after one ECAP pass: (a) shear bands, (b) corresponding SAED pattern, (c) twins, (d) corresponding SAED pattern

shows that the mirror spots of the diffraction pattern appeared with respect to the $(10 \overline{1} 1)$ plane, indicating that the two adjacent bands constitute the twin structure. The same twin system was observed in many other regions.

As CP-Ti is of hcp structure, its number of the slip system is fewer than that of the metals with fcc and bcc crystal structure. During ECAP, dislocation glide accommodates most of the imposed strain, and (10 11$)$ deformation twinning assists in the activaction of secondary slip systems. Therefore, such a mixture of the slip of dislocation and mechanical twins is the typical microstructure of CP-Ti during ECAP at room temperature.

After the second pass, shear band is still the main deformed microstructure, but its width is smaller than that after the first pass, about $0.35 \mu \mathrm{m}$. In addition, many dislocation cell blocks appear obviously in the band structure. Shear bands with different orientations intercross each other and also constitute cell structure. With increasing of the number of ECAP passes, these structures develop into subgrains. As shown in Fig.3c, there are few dislocations in subgrains. The subgrain boundaries consist of high dislocation density walls. During the fourth ECAP pressing, the grains are refined to about $250 \mathrm{~nm}$. The corresponding SAED pattern shows diffraction arranged in circles, attesting to the existence of high angle grain boundaries. Elongation of diffraction spots indicates the existence of high internal stress, the diffusion of most grains boundaries and high-energy state. These microstructural features present typical characteristics of the material processed by $\operatorname{ECAP}^{[10]}$.

\subsection{Mechanical properties}

The mechanical properties of as-pressed $\mathrm{Ti}$ at different ECAP passes are listed in Tab.1. It can be seen that with increasing of number of ECAP pass, yield strength, ultimate tensile strength and microhardness gradually increase. The great changes in grain refinement and microstructure evolution take 


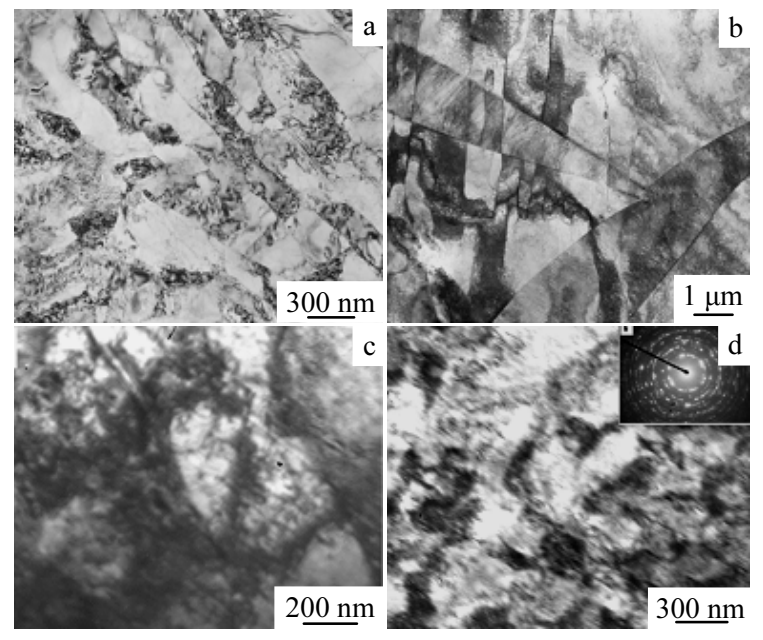

Fig.3 TEM images of CP-Ti after different ECAP passes: (a) one pass, (b) two passes, (c) three passes, and (d) four passes

Table 1 Mechanical properties of CP-Ti after ECAP

\begin{tabular}{ccccc}
\hline Processing state & YS/MPa & UTS/MPa & $\delta / \%$ & HV/MPa \\
\hline Coarse-grained & 390 & 474 & 36.4 & 1589 \\
ECAP(1) & 520 & 619 & 18.2 & 2067 \\
ECAP(2) & 580 & 703 & 17.03 & 2405 \\
ECAP(3) & 640 & 730 & 14.53 & 2450 \\
ECAP(4) & 680 & 773 & 16.82 & 2486 \\
\hline
\end{tabular}

During ECAP, there could be three strengthening mechanisms to strengthen CP-Ti: (a) grain boundary strengthening due to the formation of band structure and grain refinement; (b) dislocation strengthening resulted from increasing of dislocation density;

(c) twin strengthening because of the appearance of large number of mechanical twins.

place after the first pass. Ultimate tensile strength and microhardness are increased to 619 and $2067 \mathrm{MPa}$, respectively.
After 4 ECAP passes, the yield strength and ultimate strength are increased to 680 and $773 \mathrm{MPa}$; respectively, at the same time a good ductility of $16.8 \%$ elongation is still remained. The microhardness significantly is enhanced from 1589 to $2486 \mathrm{MPa}$.

\section{Conclusion}

After 4 ECAP passes, the initial grains are refined from $28 \mu \mathrm{m}$ to $250 \mathrm{~nm}$, and the materials with UFG and high angle grain boundaries can be obtained. Their yield strength enhances by $74 \%$ from 390 to $680 \mathrm{MPa}$. Ultimate tensile strength enhances by $63 \%$ from 474 to $773 \mathrm{MPa}$; meanwhile sufficient ductility of $16.8 \%$ elongation to failure still remains

\section{References}

1 Valiev R Z et al. Prog Mater[J], 2000, 45: 103

2 Lee B S et al. Mater Sci Eng[J], 2007, 303: 1087

3 Lee J C et al. Acta Mater[J], 2002, 50: 400

4 Berbon P B et al. Acta Mater[J], 2002, 50: 4005

5 Kamachi M et al. Mater Sci Eng[J], 2002, 347A(1-2): 223

6 Zhu Y T et al. Mater Sci Eng[J], 2000, 291A: 46

7 Shin D H et al. Acta Mater[J], 2000, 48(9): 2247

8 Shin D H et al. Scr Mater [J], 2000, 42(7): 695

9 Semiatin S L et al. Metall Mater Trans[J], 1999, 30A(5): 1425

10 Stolyarov V V et al. Mater Sci Eng[J], 2001, 299 A: 59

11 Chang-Young Hyun et al. Diffusion and Defect Data Part B (Solid State Phenomena), 2007, 124-126: 1385

12 Chon S H et al. Key Eng Mater[J], 2007, 345-346: 125

13 Kim I et al. Scripta Mater[J], 2003, 48: 813

14 Kim I et al. Mater Sci Eng[J], 2003, 342A: 302

15 Shin D H et al. Acta Mater [J], 2003, 51: 983

16 Iwahashi Y et al. Acta Mater [J], 1998, 46(9): 3317

\title{
工业纯钛在 $120^{\circ}$ 模具中的多道次 ECAP 室温变形组织与性能
}

\author{
杨西荣，赵西成，付文杰 \\ (西安建筑科技大学, 陕西 西安 710055)
}

\begin{abstract}
摘 要: 在室温, 采用通道夹角为 $120^{\circ}$ 的变形模具对工业纯钛(Commercial Pure Titanium, CP-Ti) 以 Bc 方式实施四道次 ECAP (Equal Channel Angular Pressing)挤压变形, 成功获得表面光滑无裂纹的变形试样。文中主要研究了工业纯钛在室温下进行 ECAP 多道次变形的 组织结构演变, 并测试了变形试样的力学性能。微观结构显示工业纯钛在室温下进行多道次 ECAP 变形时, 只在前两道次产生了大量的 变形孪晶, 且随道次增加变形孪晶逐渐消失。最终获得的试样晶粒平均尺寸由最初的约 $28 \mu \mathrm{m}$ 细化到约 $250 \mathrm{~nm}$, 试样断裂强度和显微 硬度分别提高到 773 和 $2486 \mathrm{MPa}$ ，而试样仍保持较好的延伸率（可达 $16.8 \%$ )。
\end{abstract}

关键词: 等径弯曲通道变形(ECAP); 工业纯钛(CP-Ti); 组织结构; 机械性能

作者简介: 杨西荣, 男, 1971 年生, 博士研究生, 副教授, 西安建筑科技大学冶金工程学院, 陕西 西安 710055, 电话: 029-82205561 